\title{
Лингвокультурологический анализ концепта «дружба» в русском языке: паремиологический и ассоциативный аспекты
}

В современной науке язык изучается в рамках антропоцентрического подхода и определяется как «зеркало культуры», которое отражает окружающую нас действительность и является важной и неотъемлемой духовной частью этой культуры, человека и всего народа. По мнению В.А. Масловой, в этом заключается важнейшее достижение современной лингвистики, поскольку «язык уже не рассматривается “в самом себе и для себя” [...] Язык — это вербальная сокровищница нации, средство передачи мысли, которую он «упаковывает» в некую языковую структуру» ${ }^{1}$.

С конца XX столетия особую актуальность среди российских лингвистов приобрели лингвокультурологические исследования (Н.Ф. Алефиренко, Ю.Д. Апресян, Н.Д. Арутюнова, Н.С. Болотнова, С.Г. Воркачев, Е.И. Зиновьева, В.И. Карасик, Ю.Н. Караулов, Е.С. Кубрякова, Е.А. Пименов, М.В. Пименова, Ю.С. Степанов, В.Н. Телия, Е.В. Урысон, А.Д. Шмелев, Е.А. Юрина, Е.Е. Юрков и многие другие), отражающие взаимоотношения и взаимосвязь языка и культуры, основным предметом изучения которых является концепт. Концепт - это «основная единица ментальности, заключающая в себе яркое образное представление и пучок ассоциаций и коннотаций, репрезентируемая вербально языковыми единицами разных уровней»².

1 В.А. Маслова. Введение в когнитивную лингвистику: Учебное пособие, Москва 2011, c. 4 .

2 Е.И. Зиновьева, Е.Е. Юрков. Лингвокультурология: теория и практика, СанктПетербург 2009, с. 94. 
Концепты представляют собой ключевые слова, некие центральные точки культуры ${ }^{3}$, которые играют значимую роль для отдельно взятой страны и ее народа. Именно поэтому концепт является «единицей коллективного знания/сознания [...], отмеченной этнокультурной спецификой» ${ }^{4}$. Лингвокультурный концепт ${ }^{5}$ характеризуется тем, что в нем фиксируются ценности определенного социокультурного пространства и его представителей, то есть содержит в себе «акцентуацию ценностного элемента» 6 .

Н.Ф. Алефиренко выделяет следующие типы ценностей, которые чаще всего попадают в поле изучения лингвокультурологов, а именно: витальные, сочиальные, политические, моральные, религиозные, эстетические. К ключевым лингвокультурным концептам моральных ценностей относят дружбу, любовь, долг, честь, добро и др. ${ }^{7}$

В данной статье представлен анализ концепта «дружба», который носит релевантный характер для большинства лингвокультур и является высшей духовной ценностью. Дружба имеет вербальное выражение в каждом языке и является важной универсальной культурозначимой единицей, однако, в зависимости от лингвокультуры и ценностных установок концепт «дружба» может бытьп редставлен разным лексико-семантическим полем, которое определяется особенностями конкретного языка.

Этот калейдоскопический концепт ${ }^{8}$ содержит в себе важные эмоционально-оценочные коннотации ${ }^{9}$. Концепт «дружба» служит эталоном межличностных отношений и является важной частью концептосферы русского народа, в связи с чем помогает смоделировать и представить фрагмент языковой картины мира России. Изучение модели концепта «дружба» (мужская дружба, женская дружба) и лексических доминант (друг, подруга, дружеский) позволяет эксплицировать ценностные ориентации представителей российского общества.

3 А. Вежбицкая. Понимание культур через посредство ключевых слов, Москва 2001.

4 С.Г. Воркачев. Счастье как лингвокультурный концепт, Москва 2004, с. 51.

5 См. критерии лингвокультурных концептов. О.А. Ипанова. Концепт «жизнь» в русской языковой картине мира: лингвокультурологический и лексикографический aсnекты. Автореф. дис. канд. филол. наук, Санкт-Петербург 2005.

6 Е.И. Зиновьева, Е.Е. Юрков. Лингвокультурология: теория и практика, Санкт-Петербург 2009, с. 122.

7 Н.Ф. Алефиренко. Лингвокультурология: иеенностно-смысловое пространство языка, Москва 2013, с. 9.

8 Согласно классификации лексических концептов А.П. Бабушкина. Tuпы концептов в лексико-фразеологической семантике языка, Воронеж 1996.

9 Калейдоскопические концепты являются «результатом метафоризации, они не имеют постоянных фиксированных ассоциатов, поскольку развертываются то в виде мыслительных картинок, то в виде фрейма, схемы или сценария». О.И. Лыткина. К вопросу о типологии концептов в современной лингвистике, "Вестник Московского государственного гуманитарного университета им. М.А. Шолохова. Филологические науки”. Выпуск № 2/ 2010.

Slavica Wratislaviensia 164, 2017

(C) for this edition by CNS 
Исследуемый нами концепт «дружба» наиболее подробно проанализирован в трудах таких ученых, как А. Вежбицкая (2001), А.Д. Шмелев (2002), А.О. Арапова (2004, 2005), Р.М. Гайсина (2005), М.А. Хизова (2005), М.Ф. Масгутова (2010).

В данном исследовании в качестве иллюстративного материала были использованы два источника, которые взаимодополняют друг друга и помогают наиболее полно представить исследуемый лингвокультурный концепт. Прежде всего, изучение концепта «дружба» было реализовано на материале, собранном по данным толковых, фразеологических и ассоциативных словарей. Концепты культуры отличаются тем, что часто входят в состав фразеологизмов, к которым относят несколько разнородных типов словосочетаний: идиомы, фразеологические сочетания, паремии, крылатые слова, клише и речевые штампы ${ }^{10}$. Данные языковые единицы представляют этнокультурную значимость и отражают особое видение мира конкретного народа. Именно поэтому фразеологические словари были использованы нами в качестве эмпирической базы. Кроме того, изучение культурной доминанты «дружба» было реализовано в рамках ассоциативного эксперимента, который помог смоделировать лексико-семантическое поле (ЛСП) слова-стимула «дружба» и, таким образом, представить фрагмент современной русской языковой картины мира в динамике, определив статус исследуемого концептуального представления в иерархии ценностей носителей русского языка, а также выделить современные общественные тенденции и возможные изменения в языковой актуализации данного концепта. Ассоциативное поле демонстрирует частотность лексических единиц, находящихся в живом употреблении.

\section{Толковые словари русского языка}

Поскольку «толковые словари выступают в качестве первого источника не только лингвистической, но и культурной информации» ${ }^{11}$, обратимся к словарным дефинициям, на основе которых можно выделить ключевые семантические признаки (семы), формирующие ядро концепта «дружба»" ${ }^{12}$, а именно: близкие отношения, взаимное доверие, привязанность, духовная близость, общность интересов, взаимная расположенность ${ }^{13}$. Основное

10 Л.Ю. Буянова, Е.Г. Коваленко. Русский фразеологизм как ментально-когнитивное средство языковой концептуализации сферы моральных качеств личности, Москва 2013, c. 7-8.

11 Г.В. Приходько. Репрезентация концептосферы дружба в толковых словарях XXХХІ веков, “Вестник НГУ. Серия: История, филология”. 2009, Т. 8. Выпуск 2, с. 22.

$12 \mathrm{Cp}$. ядерные семы слова «друг», которые выявлены на основе данных толковых словарей XX-начала XXI веков: взаимность, близость, привязанность, симпатия, общение, личностные отночения, доброжелательность, расположение, искренность, доверие, интенсивность, единодушие, согласие. Ibidem, с. 25.

13 Данные семы приводятся по: В.И. Даль. Толковый словарь русского языка, Москва 2016; С.И. Ожегов, Н.Ю. Шведова. Толковый словарь русского языка, Москва 2006; С.А. Куз- 
значение, которое встречается в толковых словарях, звучит следующим образом: дружба - это отношения между людьми, основанные на духовной близости, взаимности, доверии, привязанности и общности интересов.

\section{Ассоциативные словари}

Семы (от стимула к реакции), наиболее часто актуализирующиеся в $P y c$ ском ассоичативном словаре Ю.Н. Караулова, представляют ядро концепта «дружба» (количество актуализаций представлено в скобках): крепкая (17), народов (17) ${ }^{14}$, любовь (6), верная (5), навеки (5).

Отметим также ядерные семы слова «друг», выявленные на основе материалов таких ассоциативных словарей, как Русский ассоциативный словарь Ю.Н. Караулова (РАС), Словарь ассоциативных норм русского языка А.А. Леонтьева (САНРЯ), Славянский ассоичативный словарь Н.В. Уфимцевой (CAC). Для выражения реакции на слово-стимул «друг» чаще всего использовались существительные и прилагательные, а также притяжательное местоимение мой (ср. РАС - индекс частотности 28, САС-21, САНРЯ-10). Среди ядерных сем имени существительного особое место занимают антонимы слова «друг»: враг (САС-82, РАС-47, САНРЯ-30) и недруг (САС-22, РАС-9, САНРЯ-9). Преобладают существительные в именительном падеже: товарищ (САНРЯ-39, РАС-27, САС-21), собака ${ }^{15}$ (САС-20, РАС-17), брат (СAC-17, РАC-10), подруга (САС-13, РАС-10), верность (САС-11), помошь (САС-10), надежность (САС-8). Необходимо также отметить частотное словосочетание друг детства (РАС-33).

Особое место среди реакций на слово «друг» занимают также прилагательные: верный (РАС-69, САС-62, САНРЯ-29), лучиий (САС-23, РАС-20), хороший (САС-23, РАС-16, САНРЯ-16), близкий (РАС-16, САС-8, САНРЯ-5), мильй (РАС-12), единственный (РАС-9), надежный (РАС-9), настоящий (РАС-9, САНРЯ-4), преданный (САС-8), закадычный (т.е. задушевный, близкий) $(\mathrm{PAC-8})^{16}$, старый (САНРЯ-4).

нецов. Большой толковый словарь русского языка, Санкт-Петербург 1998; Т.Ф. Ефремова. Новый словарь русского языка. Толково-словообразовательный, Москва 2000; Д.Н. Ушаков, Толковый словарь русского языка: около 30000 слов, Москва 2007.

14 Дружба народов - «отношения между народами, странами, государствами, основанные на доверии, взаимопонимании и невмешательстве во внутренние дела друг друга» по: С.А. Кузнецов. Большой толковый словарь русского языка, Санкт-Петербург 1998, c. 285 .

15 См. собака - лучший друг человека.

16 См. фразеологическое сочетание «закадычный друг». Прил. «закадычный» образовалось от выражения «залить за кадык», то есть выпить спиртного напитка, соответственно, первоначально закадычный друг — «друг по застолью, по выпивке» по: Г.А. Крылов. Этимологический словарь русского языка. Санкт-Петербург 2005, с. 141. 


\section{Фразеологические словари. Паремиологический аспект}

В диссертационном исследовании «Конщепт “Дружба": системный и функционально-когнитивный анализ» (2004) О.А. Арапова подчеркивает, что «центральным постулатом этической модели дружбы является признание дружеских отношений величайшим благом, счастьем и необходимым условием полноценной человеческой жизни» ${ }^{17}:$ Kто не имеет друга - живет наполовину; Нет друга, так ищи, а нашел, так береги ${ }^{18}$. Дружбу можно завязать, водить, дружба может клеиться или не клеиться, сойти на нет, затрещать по швам.

Семантика «дружбы» связана с любовью и симпатией, которые, в свою очередь, относятся к эмоциональной и чувственной сферам. Дружеские отношения приносят радость и удовольствие от общения. Фразеологическое выражение шутливо-непринужденного характера «друг ситный» содержит в себе данную коннотацию ${ }^{19}$.

В языковом сознании носителей русского языка существуют определенные устойчивые коннотации, связанные с концептом «дружба». Модель концепта «дружба» строится на основе фрейма, представляющего образ близкого человека, с которым, как правило, не имеется родственной связи (однако довольно часто другом, а иногда и лучшим другом, называют кого-либо из членов семьи), но с которым объединяет духовная близость; эти отношения отличают взаимность, привязанность и родство душ.

\section{Пресуппозиция «помощи и поддержки»}

Фрейм дружбы также строится как модель ситуации, связанной с поддержкой, помощью (эмоциональной, финансовой), а также спасением товарища, попавшего в трудную ситуацию, беду. Пресуппозиция, существующая в языковом сознании носителей русского языка, «помощи и поддержки в трудную минуту», «совместного преодоления беды» реализуется в следующих широко известных пословицах: Друзья познаются в беде; Друг познает-

17 О.А. Арапова. Кониепт «Дружба»: системный и функиионально-когнитивный анализ. Автореф. дис. канд. филол. наук, Уфа 2004, с. 25.

18 Здесь и далее пословицы на русском языке приводятся по: М.А. Рыбникова. Русские пословицы и поговорки, Москва 1961, с. 84-85; В.И. Даль. Избранные пословищы русского народа: Словарь, Москва 2012, с. 88-91; В.М. Мокиенко, Т.Г. Никитина, Е.К. Николаева. Большой словарь русских пословии, Москва 2010, с. 300-306.

19 Выражение друг ситный (прост. шутл. или ирон.) связано с выпечкой хлеба из муки, просеянной через сито. Этот ситный хлеб подавали к чаю с медом и творогом и ели его с большим удовольствием, поэтому изначально «ситный друг - человек, при общении с которым испытываешь удовольствие», соответственно, «хороший друг»; затем обращение стало употребляться насмешливо, иронически. Д.Э. Розенталь. Фразеологический словарь русского языка, Москва 2008, с. 94. 
ся в несчастье; Истинный друг познается в нужде; Коли дружбу водить, так в беде помогать; С мильм другом и горе пополам разгорюешь; Назвался другом - помогай в беде; Не считай друга в гульбе, а считай в беде; Коня в рати узнаешь, а друга в беде; Сам умирай, а друга выручай; Друг всегда приходит вовремя; Есть дружок - есть заступничек; За добрым другом как за каменной стеной. Настоящий друг спешит на помощь, невзирая ни на что: «Друзья образуют важную социальную категорию: это люди, на которых можно положиться, когда надо найти помощь и поддержку» ${ }^{20}$.

Кроме готовности помогать в любой сложной ситуации, Анна Вежбицкая отмечает среди главных элементов, составляющих концепт «дружба», «интенсивное и задушевное личное общение» ${ }^{21}$, которое, на наш взгляд, основано на искренности, особой эмоциональной и духовной близости, возможности «излить душу» своему другу. По мнению А.Д. Шмелева, «интенсивное и задушевное личное общение »не является главным в концепте «дружба», центральной является «идея - помочь в случае необходимости» ${ }^{22}$. Автор отмечает, что дружба может быть прервана, но, несмотря на отсутствие общения в течение многих лет, настоящий друг всегда придет на помощь и не подведет.

\section{Пресуппозиция «сходства и общности интересов», «влияния друг на друга»}

Не только близость, которую невозможно ничем расторгнуть (Их водой не разольешь), но и особое сходство друзей являются релевантными признаками концепта «дружба». Пресуппозиция 'сходства и общности интересов', а также 'большого влияния друзей друг на друга' реализуется в таких паремиях русского народа, как Какову дружбу заведешь, такову и жизнь поведешь; К кому будешь вхож, на того будешь и похож; Скажи, с кем ты дружен, ия скажу, кто ты таков; С кем поведешься, от того и наберешься. В связи с сильным влиянием друзей на жизнь человека известные русские пословицы гласят: Ищи товарища лучше себя, а не хуже себя; Не бойся врага умного, бойся друга глупого.

Амбивалентную оценочную коннотацию имеет диминутив «дружок». Отрицательная ассоциация этого слова вытекает из неодобрения по отношению к кому-либо, оказывающему дурное влияние, втягивающему в скверные дела ${ }^{23}$.

20 А. Вежбицкая. Понимание культур через посредство ключевых слов, Москва 2001, c. 109.

21 Ibidem, c. 112.

22 А.Д. Шмелев. Русская языковая модель мира: Материаль к словарю, Москва 2002, c. $183-184$.

23 С.И. Ожегов, Н.Ю. Шведова. Толковый словарь русского языка: 80000 слов и фразеологических выражений, Москва 2006, с. 181. 


\section{Пресуппозиция «счастья», «верности и надежности»}

Дружба помогает отделить «своих» от «чужих», таким образом, дружеские отношения - это отношения, основанные на эмоции радости и счастья (ср. Кто дружбу водит, тот счастье находит; Дружка нет: не мил и бельй cвет) и совместном времяпрепровождении, в центре которых находится «свой» человек (свой в доску). Общие интересы, а также чувство привязанности, доверия, верности и надежности выделяют «своего» человека среди «чужих». Верность и надежность реализуются в следующих пословицах: Друг верен и неизменен; Друг тогда, когда он рядом; Плохи друзья на полчаса; На того друга надеяться можно, который верен не ложно; От верного друга не отлучайся и всегда на него надейся; Верному другу иены нет.

Друг может быть старым (дружба, проверенная временем) или новым. Противопоставление старый друг-новый друг находим в таких выражениях, как Старый друг лучше новых двух; Новых друзей наживай, а старых не забывай (не теряй); Все добро, что ново, а друг, когда стар; Друга узнать вместе пуд соли съесть; Не хвались другом в три дня, а хвались в три года.

\section{Пресуппозиция «бескорыстия»}

Среди русских паремий, отражающих представления русского народа о дружбе, мы находим известные речения, в которых дружба как одна из высших духовных ценностей противопоставляется материальной стороне: Не имей сто рублей, а имей сто друзей; Друга на деньги не купишь; Дружба дороже денег; Доброе братство милее богатства. В этих пословицах содержится один из главных признаков, который представляет собой ядро концепта «дружба», а именно: приоритет дружбы над ценностью материальных и финансовых благ.

Среди известных пословиц русского народа можно также выделить паремии с компонентом «деньги», в которых подчеркивается его несовместимость с понятием «дружба»: Дружба дружбой, а в карман не лезь; Дружба дружбой, а денежки сами по себе; Дружба дружбой, а денежкам счет; Дружба дружбой, а деньги счет любят; Дружба дружбой, а табачок врозь; Хочешь нажить себе врага - одолжи другу денег. В вышеуказанных примерах присутствует некий элемент упрека и разочарования, поскольку деньги могут разрушить дружеские отношения. Представленные пословицы описывают ситуацию, когда кто-то из друзей поступает эгоистично из-за личных расчетов, не по-дружески, а значит вопреки ожиданиям о настоящей дружбе.

Как известно, дружеские отношения не всегда бывают бескорыстными, нередко они строятся на выгоде: Много друзей, у кого деньгам вод; Много друзей, коли денежки есть; Хлеба нет - друзейи не бывало; Дружба в обед, 
а как скатерть со стола - и дружба спльла; Как при пире, при беседе много друзей, как при горе, при кручине - нет никого.

\section{Ассоциативный эксперимент}

Изучение данного концепта позволяет определить основные черты и релевантные ценности, наиболее ярко и показательно характеризующие лингвокультурное пространство современной России. Ассоциативный эксперимент, участие в котором приняли 80 человек обоих полов (18 мужчин, 62 женщины) в возрасте 21-33 лет, помогает представить ассоциативно-вербальное поле концепта «дружба». В рамках проведенного психолингвистического эксперимента респонденты описывали свои ассоциации, связанные со словом-стимулом «дружба» (женская, мужская). В ходе исследования также были выявлены ассоциативные реакции на стимулы «друг», «подруга», «дружеский».

Респонденты в качестве реакции на слово-стимул «дружба» чаще всего использовали существительные. В таблице 1 представлены ядро и периферия (на периферии остаются слова и субстантивные словосочетания (имя сущ. + имя прил.), которые встречаются менее двух раз) лексико-семантической группы (ЛСГ) существительных. Затем по численности преобладают имена прилагательные, ЛСГ которых представлена лексемами: близкий

Табл. 1. ЛСГ существительных ассоциативного поля «дружба»

\begin{tabular}{|c|c|c|}
\hline Ядро ЛСП «дружба» & $\begin{array}{l}\text { Периферия ЛСП «дружба» } \\
\text { (2 реакции) }\end{array}$ & $\begin{array}{l}\text { Периферия ЛСП «дружба» } \\
\text { (1реакция) }\end{array}$ \\
\hline $\begin{array}{l}\text { (взаимо-)понимание (25) } \\
\text { доверие (24) } \\
\text { (взаимо-)поддержка (17) } \\
\text { отношения (12) } \\
\text { (взаимо-) помощь (11) } \\
\text { /общие/ интересы (8) } \\
\text { уважение (6) } \\
\text { любовь (4) } \\
\text { радость (4) } \\
\text { чувство (4) } \\
\text { связь (3) } \\
\text { родство (3) } \\
\text { счастье (3) } \\
\text { смех (3) } \\
\text { ценность (3) } \\
\text { искренность (3) } \\
\text { жизнь (3) } \\
\text { готовность (3) }\end{array}$ & $\begin{array}{l}\text { веселье } \\
\text { /яркие/ моменты } \\
\text { привязанность } \\
\text { бескорыстие } \\
\text { забота } \\
\text { самоотдача } \\
\text { слабости } \\
\text { ошибки } \\
\text { откровения } \\
\text { надежность } \\
\text { трудная ситуация }\end{array}$ & $\begin{array}{l}\text { подарок } \\
\text { судьба } \\
\text { добро } \\
\text { секреты } \\
\text { богатство } \\
\text { симпатия } \\
\text { толерантность } \\
\text { свобода } \\
\text { верность } \\
\text { честность } \\
\text { длительность } \\
\text { юмор } \\
\text { горе } \\
\text { переживания } \\
\text { сочувствие } \\
\text { взаимовыручка } \\
\text { увлечения } \\
\text { кафе } \\
\text { прогулки }\end{array}$ \\
\hline
\end{tabular}


- 6 реакций; бескорыстныци - 2; искренний, любимыци, святой, честный, эмоччиональный — 1; а также ЛСГ глаголов: поддержать - 3; понимать, пережить, прощать - 2; любить, выслушать, молчать, радоваться, проводить время, помочь, положиться - 1. Опрос носителей языка показал, что дружба воспринимается как связь между людьми (чувство взаимной привязанности), основанная на доверии, поддержке, взаимопонимании, взаимопомощчи, общчих интересах и уважении.

В рамках данного исследования важное место занимает ассоциативно-вербальное поле женской и мужской дружбы. В русской лингвокультуре необходимо отметить противопоставление женской дружбы мужской, поскольку считается, что мужская дружба крепче. Главное отличие заключается в потребности обсуждать свои чувства и эмоции, которая обычно

Табл. 2. ЛСГ существительных ассоциативного поля «женская дружба»

\begin{tabular}{|c|c|c|}
\hline $\begin{array}{l}\text { Ядро ЛСП «женская } \\
\text { дружба» }\end{array}$ & $\begin{array}{l}\text { Периферия ЛСП «женская } \\
\text { дружба» (2 реакции) }\end{array}$ & $\begin{array}{l}\text { Периферия ЛСП «женская } \\
\text { дружба» (1 реакция) }\end{array}$ \\
\hline $\begin{array}{l}\text { поддержка (11) } \\
\text { понимание (8) } \\
\text { интересы (7) } \\
\text { доверие (6) } \\
\text { помощь (6) } \\
\text { сплетни (4) } \\
\text { разговоры (3) } \\
\text { смех (3) } \\
\text { секреты (3) } \\
\text { симпатия (3) } \\
\text { парни (3) }\end{array}$ & $\begin{array}{l}\text { совет } \\
\text { любовь } \\
\text { уважение } \\
\text { требовательность } \\
\text { искренность } \\
\text { умение } \\
\text { общение } \\
\text { проблемы } \\
\text { трудная ситуация } \\
\text { трудная минута } \\
\text { переживания } \\
\text { недосказанность } \\
\text { непостоянность }\end{array}$ & $\begin{array}{l}\text { привязанность } \\
\text { счастье } \\
\text { честность } \\
\text { сотрудничество } \\
\text { взаимовыручка } \\
\text { тыл } \\
\text { сопереживание } \\
\text { забота } \\
\text { вера } \\
\text { веселье } \\
\text { слезы } \\
\text { ссоры } \\
\text { примирение } \\
\text { болталки }{ }^{24} \\
\text { болтливость } \\
\text { телефон } \\
\text { тайны } \\
\text { встречи } \\
\text { магазин } \\
\text { переменчивость } \\
\text { соперничество } \\
\text { предательство } \\
\text { хитрость } \\
\text { лукавость } \\
\text { миф } \\
\text { фикция } \\
\text { /временное/ явление }\end{array}$ \\
\hline
\end{tabular}

24 Жаргонная лексика, в значении 'разговоры, беседы'. 
отсутствует в дружеских отношениях между мужчинами. Мужская дружба часто ассоциируется с такими прилагательными, как крепкая, прочная, сильная, а женская дружба - как недолговечная и ненадежная.

Ассоциативные реакции респондентов на понятие «женская дружба» выражены, прежде всего, с помощью имен существительных и атрибутивных отношений, возникающих при семантико-грамматическом воздействии имен существительных с именами прилагательными (например, временное явление). В таблице 2 представлена ЛСГ существительных, ассоциирующихся с женской дружбой в русской лингвокультуре, которые входят в ядро и периферию интересующего нас поля. Необходимо выделить также ЛСГ глаголов (выслушать, говорить - 3; сказать, поделиться, прощать - 2; дать, радоваться, посмеяться, помочь, советовать, хранить, обсудить, выговориться - 1) и ЛСГ имен прилагательных (общий - 5; трудный - 3; весельй, надежный, эмоцчиональный - 2; верный, искренний, тепльй, нежный, чувственный, уютный, родственныли, сестринский, временный, недолговечный, ненадежный, хрупкий - 1). На основании полученных данных можно сделать вывод о том, что для жителей социокультурного пространства России женская дружба - это дружба, которая основана на поддержке, взаимопонимании, взаимопомощчи, общзих интересах, доверии, симпатии, разговорах, секретах, сплетнях.

Для выражения реакции на словосочетание «мужская дружба» также чаще всего использовались существительные либо субстантивные словосочетания с конструкцией имя сущ. + имя прил. (ср., мужское слово, мужские дела); слова, которые встречаются в ответах опрошенных менее двух раз, представляют периферию ассоциативного поля (см. Табл. 3). Необходимо также отметить ЛСГ прилагательных (крепкий - 5; сильный, долгий, искренний, удивительный, совместный - 2, доверительный, задушевный, длительный, настоящий, интересный, прочный, грубый, твердый, земной, простой, взаимовыгодный - 1) и глаголов (поддержать, разрешать проблемь, помочь, не подставить, позвонить, попросить, проводить время, выпить, пойти - 1). Таким образом, мужская дружба - это отношения, основанныле на поддержке, преданности, взаимовыручке, взаимопонимании, силе, взаимопомоши, верности, солидарности, общих интересах (например, в рамках ассоциативного эксперимента можно выделить пиво, машины, спорт и пр.) и уважении.

Слова «друг»/«подруга» ассоциируются у жителей лингвокультурного пространства России с похожими качествами. Друг - это близкий человек, на которого можно всегда положиться. Поддержка в трудную минуту, понимание, доверие, надежность, умение радоваться являются главными признаками и ценностными установками настоящего друга. В свою очередь, подруга - это близкий человек, который всегда выслушает, поможет, поддержет.

Как показали результаты эксперимента, в языковой картине мира русской лингвокультуры слово-стимул «дружеский» ассоциируется с такими прилагательными, как близкий, искренний - 8; хороший, приятныци - 7; доб- 
Табл. 3. ЛСГ существительных ассоциативного поля «мужская дружба»

\begin{tabular}{|c|c|c|}
\hline $\begin{array}{l}\text { Ядро ЛСП «мужская } \\
\text { дружба» }\end{array}$ & $\begin{array}{l}\text { Периферия ЛСП «мужская } \\
\text { дружба» (2 реакции) }\end{array}$ & $\begin{array}{l}\text { Периферия ЛСП «мужская } \\
\text { дружба» (1 реакция) }\end{array}$ \\
\hline $\begin{array}{l}\text { поддержка (13) } \\
\text { понимание (6) } \\
\text { взаимовыручка (6) } \\
\text { сила (6) } \\
\text { отношения (5) } \\
\text { помощь (5) } \\
\text { верность (5) } \\
\text { преданность (5) } \\
\text { солидарность (5) } \\
\text { общие интересы (5) } \\
\text { уважение (5) } \\
\text { доверие (4) } \\
\text { разговоры (4) } \\
\text { пиво (4) } \\
\text { машины (3) }\end{array}$ & $\begin{array}{l}\text { /мужское/ слово } \\
\text { явление } \\
\text { надежность } \\
\text { братство } \\
\text { единство } \\
\text { привязанность } \\
\text { прямота } \\
\text { искренность } \\
\text { симпатия } \\
\text { отдых } \\
\text { увлечения } \\
\text { женщины }\end{array}$ & $\begin{array}{l}\text { родство } \\
\text { готовность } \\
\text { твердость } \\
\text { крепость } \\
\text { стабильность } \\
\text { тишина } \\
\text { неосуждение } \\
\text { вера } \\
\text { честь } \\
\text { паритет } \\
\text { трудная ситуация } \\
\text { проблемы } \\
\text { открытость } \\
\text { /мужские/ дела } \\
\text { общение } \\
\text { посиделки }{ }^{25} \\
\text { беседы } \\
\text { приключения } \\
\text { приколы } \\
\text { в } \\
\text { веселье } \\
\text { тренажерный зал } \\
\text { спорт } \\
\text { бар } \\
\text { пятница / суббота } \\
\text { девушки } \\
\text { ремонт } \\
\text { память } \\
\text { молодость } \\
\text { редкость } \\
\text { миф }\end{array}$ \\
\hline
\end{tabular}

рый - 6; бескорыстнылй, открытылй, отзывчивылй, честныци, надежный 4; доброжелательныц̆, тепльй, родной, беззлобный, безопаснылй, общзий — 3; мирный, понимающчй, положительнылй, чистылй, братский, душевный, любезный, уютный, безвредный — 2; позитивный, активный, весельій, приятельский, приветливый, сердечный, партнерский, общительный, жизнерадостный, внимательнылй, коммуникативный, мильй, взаимнылй, яснылй, настоящий, благожелательный, верный, свободный, спокойный - 1. Необ-

25 В настоящее время чаще всего посиделки - значит дружеские встречи, теплое общение, беседы. Согласно словарю С.И. Ожегова и Н.Ю. Шведовой, «посиделки зимняя вечеринка молодежи в старой русской деревне, сопровождающаяся каким-то занятием, ручной работой. Не рекомендуется употреблять в значении вечеринка». Толковый словарь русского русского языка, Москва 2006, с. 567.

26 Молодежный сленг, то же, что 'розыгрыш, шутка, что-то смешное'; nрuкальвваться - значит 'шутить, разыгрывать'. 
ходимо также отметить имена существительные и языковые конструкции предлог без + имя сущ. (совет - 8; жест, отношения - 4; действия, разговор, почелуй - 3; поступок, помощь - 2; вежливость, доброжелательность, вечер, рукопожатие, шаг, союз, взгляд, без подтекста, без упрека, без претензий - 1), а также ЛСГ причастий (помогающий - 2; любящий, желающий добра, ненапрягающчий, необязующий, располагающий - 1). Следовательно, дружеский - значит близкий, искренний, хороший, приятный, добрый, бескорыстнылй, открытый, честнылй, надежный, отзывчивый.

Ассоциативный эксперимент помог выявить особенности функционирования концепта «дружба» и его ядерно-периферийные признаки в обыденном языковом сознании жителей современной России. Таким образом, дружба для представителей русской лингвокультуры сопряжена с таким качествами, как симпатия, уважение, верность, преданность, солидарность, надежность, отзывчивость, поддержка, соучастие, взаимовыручка, понимание, доверие, искренность и бескорыстие.

\section{Парадигматические и синтагматические связи}

Слова друг, товарищ, коллега, приятель, знакомый находятся между собой в парадигматических отношениях на лексическом уровне. Эти слова связаны по смыслу («вертикаль смысла»), однако по некоторым признакам они противопоставлены. Существует определенная коннотативная разница в представлениях о друге, товарище, приятеле, знакомом, коллеге. Именно слова «друг», «друзья», «дружба» выражают крепкую и глубокую связь, соответственно, связь с другом крепче, чем связь с товарищем, приятелем или знакомым (такие отношения носят больше общественный характер, чем личностный, и основаны, к примеру, на совместной работе). Дружеские отношения достаточно часто сравниваются с братскими ${ }^{27}$. Поэтому в разговорной речи можно встретить дружеское обращение в диминутивной форме «братишка», которое является синонимом слова «друг».

Анализ синтагматических связей, реализующих «горизонталь смысла», позволяет выделить ключевые ассоциации, возникающие вокруг концепта дружба: крепкая дружба, настоящая дружба, дружба на века, дружба и в горе, и в радости.

$$
* * *
$$

В результате лингвокультурологического анализа аксиологического концепта «дружба» в сознании носителей русского языка были выявлены следующие релевантные признаки: дружба - высшая духовная ияенность,

27 Г.В. Приходько. Репрезентация концептосферы дружба в толковых словарях XXXXI веков, „Вестник НГУ”. Серия: История, филология. 2009, Т. 8. Выпуск 2, с. 24. 
которую нельзя купить за деньги; дружба приносит счастье; дружбу отличают теплье близкие отночения; отзывчивость, надежность, помошьь в беде - главные качества настоящей дружбы; дружба основана на заботе и взаимопонимании; дружеские отношения отличают искренность; дружеские отношения основаны на бескорыстии ${ }^{28}$; общие интересы - основа дружеских отношений.

Анализ концепта «дружба» в качестве «концентрата культуры и опыта народа» ${ }^{29}$ помогает отразить общественные ценности и менталитет жителей современной России.Ключевое слово «дружба» столь важное для русской лингвокультуры, прежде всего, используется в семантической сфере, которую можно определить как сферу чувств и эмоций, и связано с моральнонравственной оценкой. Несмотря на то, что в общественной и культурной жизни происходят значимые трансформации, связанные с культурой потребления и ориентацией на материальные ценности, с развитием и преобладанием информационных технологий, дружба по-прежнему остается высшей духовной ценностью.

\section{Библиография}

\section{Источники}

Даль В.И., Избранные пословиць русского народа: Словарь, Москва 2012.

Даль В.И., Толковый словарь русского языка, Москва 2016.

Ефремова Т.Ф., Новый словарь русского языка: Толково-словообразовательный. В 2-х т., Москва 2000.

Ю.Н. Караулов, Русский ассоичативный словарь. В 2-х m. / Ю.Н. Караулов et al. От стимула к рекции: Ок. 7000 стимулов, Москва 2002, http://tesaurus.ru/dict/ dict.php.

Крылов Г.А., Этимологический словарь русского языка, Санкт-Петербург 2004.

Кузнецов С.А, Большой толковый словарь русского языка, Санкт-Петербург 1998.

Леонтьев А.А., Словарь ассоииативных норм русского языка. Прямой, Москва 1973, http:// it-claim.ru/Projects/ASIS/Leont/Index.htm.

Мокиенко В.М., Никитина Т.Г., Николаева Е.К., Большой словарь русских пословии, Москва 2010.

Ожегов С.И., Шведова Н.Ю., Толковый словарь русского языка: 80000 слов и фразеологических выражений, Москва 2006.

Розенталь Д.Э., Краснянский В.В., Фразеологический словарь русского языка, Москва 2008. Рыбникова М.А., Русские пословищь и поговорки, Москва 1961.

28 Данные ассоциативного эксперимента в процессе выявления специфики концептуального представления «дружба» подтвердили, что в сознании современных носителей русского языка нет места расчету, личным интересам и выгоде. Ср. результаты ассоциативного эксперимента и специфику реализации данного концепта в современной немецкой лингвокультуре. М.Ф. Масгутова. Специфика реализации кониептуального представления «дружба» в сознании языковой личности. Автореф. дис. канд. филол. наук, Челябинск 2010.

29 В.А. Маслова. Введение в когнитивную лингвистику: Учебное пособие, Москва 2011. 
Уфимцева Н.В., Славянский ассоииативный словарь: русский, белорусский, болгарский, украинский / Н.В. Уфимцева et al., Москва 2004, http://it-claim.ru/Projects/ASIS/SAS/ index.html.

Ушаков Д.Н., Толковый словарь русского языка: около 30000 слов, Москва 2007.

\section{Литература}

Алефиренко Н.Ф., Лингвокультурология: ценностно-смысловое пространство языка, Москва 2013.

Арапова О.А., Гайсина Р.М., Дружба, Антология концептов. Том 1, Волгоград 2005.

Арапова О.А., Концепт «Дружба»: системный и функционально-когнитивный анализ. Автореф. дис. канд. филол. наук, Уфа 2004.

Бабушкин А.П., Типы концептов в лексико-фразеологической семантике языка, Воронеж 1996.

Буянова Л.Ю., Коваленко Е.Г., Русский фразеологизм как ментально-когнитивное средство языковой кониептуализации сферы моральных качеств личности, Москва 2013.

Вежбицкая A.l, Понимание культур через посредство ключевых слов, Москва 2001.

Воркачев С.Г., Счастье как лингвокультурный концепт, Москва 2004.

Зиновьева Е.И., Юрков Е.Е., Лингвокультурология: теория и практика, Санкт-Петербург 2009.

Ипанова О.А., Концепт «жизнь» в русской языковой картине мира: лингвокультурологический и лексикографический аспекты. Автореф. дис. канд. филол. наук, Санкт-Петербург 2005.

Коняева Е.В., Концепт «дружба» по данным научных исследований, Современные коммуникации: Язык. Человек. Общество. Культура: сборник статей, Екатеринбург 2014.

Лыткина О.И., К вопросу о типологии концептов в современной лингвистике, Вестник Московского государственного гуманитарного университета им. М.А. Шолохова. Филологические науки. Выпуск № 2/ 2010.

Масгутова М.Ф., Специфика реализации конщептуального представления «дружба» в сознании языковой личности. Автореф. дис.канд. филол. наук, Челябинск 2010.

Маслова В.А., Введение в когнитивную лингвистику: Учебное пособие, Москва 2011.

Приходько Г.В., Репрезентация концептосферы дружба в толковых словарях XX-XXI веков, Вестник НГУ. Серия: История, филология. 2009, Том 8. Выпуск 2.

Хизова М.А., Концепт «дружба» в русской и английской лингвокультурах. Автореф. дис. канд. филол. наук, Краснодар 2005.

Шмелев А.Д., Русская языковая модель мира: Материалы к словарю, Москва 2002.

\section{Linguo-cultural analysis of the concept of "friendship" in Russian language: paremiological and associative aspects}

\section{Summary}

The present work is devoted to linguo-cultural analysis of the concept "friendship" in a social and cultural area in Russia. The concept of "friendship" is one of the key concepts of Russian language, which presents a fragment of linguistic picture of the world of Russian linguoculture and the mentality of the inhabitants of modern Russia. Analysis of the material of associative 
dictionaries, phraseological units and proverbs helped to draw important conclusions, which were subsequently subjected to empirical verification. Moreover, questionnaire on associations, which let us explore the concept of "friendship" and examine reactions of native Russian speakers on words-stimulus: friendship (male, female), male friend, female friend, friendly, was carried out in this paper.

Keywords: Cultural Linguistics, Russian linguistic picture of the world, concept "friendship", phraseology, paremiology.

\section{Analiza lingwokulturologiczna konceptu „przyjaźń” w języku rosyjskim: aspekt paremiologiczny i asocjacyjny}

\section{Streszczenie}

Niniejszy artykuł poświęcony jest analizie lingwokulturologicznej konceptu „przyjaźń” w rosyjskiej przestrzeni społeczno-kulturowej. Koncept „przyjaźń” jest jednym z istotnych konceptów języka rosyjskiego, który przedstawia fragment językowego obrazu świata rosyjskiej lingwokultury oraz mentalność mieszkańców współczesnych Rosjan. Analiza materiału wyekscerpowanego ze słowników frazeologicznych, paremiologicznych i asocjacyjnych pozwoliła wysnuć wiele wniosków, które następnie zostały poddane weryfikacji empirycznej. Ponadto został przeprowadzony eksperyment asocjacyjny, który pozwolił zbadać koncept „przyjaźń” i prześledzić reakcje rodzimych użytkowników języka rosyjskiego na słowa bodźce: przyjaźń (męska, kobieca), przyjaciel, przyjaciótka, przyjacielski.

Słowa kluczowe: lingwistyka kulturowa, rosyjski językowy obraz świata, koncept „przyjaźń", frazeologia, paremiologia. 